\title{
NOTE
}

\section{CUSTODIAL INTERROGATION AFTER OREGON v. MATHIASON}

In Miranda v. Arizona,${ }^{1}$ the Supreme Court established procedural safeguards protecting an individual's privilege against self incrimination while in custody "or otherwise deprived of his freedom by the authorities in any significant way . ..."2 Since that decision in 1966 courts have had to determine whether those safeguards-the famous "Miranda warnings" - apply in a wide variety of factual situations short of formal arrest. ${ }^{4}$ This determination is often crucial; if the defendant is in "custody," no statements made by him in response to police $^{5}$ questioning may be used against him at trial unless the prosecution can show that he had first received Miranda warnings and had waived his rights thereunder. ${ }^{6}$

In the 1977 case of Oregon v. Mathiason, ${ }^{7}$ the Supreme Court narrowly construed the language of Miranda, holding that "Miranda warnings are required only where there has been such a restriction on a person's freedom as to render him in custody." "8 The Mathiason Court overturned a ruling of the Oregon Supreme Court that an individual who was questioned in a "coercive environment" had been sub-

1. 384 U.S. 436 (1966).

2. Id. at 478.

3. [U]nless other fully effective means are adopted to notify the person of his right of silence and to assure that the exercise of the right will be scrupulously honored, the following measures are required. He must be warned prior to any questioning that he has the right to remain silent, that anything he says can be used against him in a court of law, that he has the right to the presence of an attorney, and that if he cannot afford an attorney one will be appointed for him prior to any questioning if he so desires. Opportunity to exercise these rights must be afforded to him throughout the interrogation.

Id. at 479.

4. See Kamisar, "Custodial Interrogation" Within the Meaning of Miranda, in Criminal LAW AND THE Constitution 333 (1968); Graham, What is "Custodial Interrogation?": California's Anticipatory Application of Miranda v. Arizona, 14 U.C.L.A. L. REv. 59 (1966); Smith, The Threshold Question in Applying Miranda: What Constitutes Custodial Interrogation?, 25 S.C. L. Rev. 699 (1974); Annot., 31 A.L.R.3d 565 (1970 \& Supp. 1978).

5. The term "police," as used in this Note, includes other law enforcement authorities as well (e.g., F.B.I. and Secret Service agents, sheriff's department staff, county detectives, etc.) unless the context indicates a more narrow application. Likewise, the term "police station," when used in a general sense, includes sheriff's offices and similar locations.

6. Miranda, 384 U.S. at 479.

7. 429 U.S. 492 (1977) (per curiam). Mathiason has been noted in the following law journals: 5 AM. J. CRIM. LAw 334 (1977); 45 FordhaM L. Rev. 1222 (1977); 23 LOY. L. Rev. 1057 (1977); 57 ORE. L. REv. 184 (1977).

8. 429 U.S. at 495 . 
jected to a "custodial interrogation"9 within the meaning of Miranda, even though he had come to the station voluntarily in response to a state policeman's request and had been told that he was not under arrest. ${ }^{10}$

Mathiason has been widely viewed as a significant contraction of the rights of the accused and as a possible augur of further contractions in the future. ${ }^{11}$ This Note will examine the impact of Mathiason in light of the previous case law under Miranda and, more particularly, will examine post-Mathiason lower court cases for trends emerging in the application of Mathiason. It will conclude that state and lower federal courts do not seem to be interpreting Mathiason as a signal for sharp curtailment of Miranda rights, but rather are largely limiting the case's application to the specific fact situation in which it arose.

\section{MiRANDA AND "Custodial InTERrogation"}

The threshold issue with respect to the applicability of Miranda's procedural requirements is clearly "custodial interrogation": "[T]he prosecution may not use statements, whether exculpatory or inculpatory, stemming from custodial interrogation of the defendant unless it demonstrates the use of procedural safeguards effective to secure the privilege against self incrimination." 12 Definition of the phrase "custodial interrogation" has proven troublesome, ${ }^{13}$ however, and courts and

9. State v. Mathiason, 275 Or. 1, 4-5, 549 P.2d 673, 675 (1976).

10. Id. at 3,549 P.2d at 674 .

11. Justice Stevens, in a dissent joined by Justices Brennan, Stewart and Marshall, has cited Mathiason as authority for the proposition that "the State's duty to give advice to an accused is contracting . . . ." Jeffers v. United States, 432 U.S. 137, 160 (Stevens, J., dissenting). See also note 67 infra.

It should be noted that the Mathiason decision was presaged by some lower court decisions. A 1974 survey concluded: "Of all the aspects of the issue of custodial interrogation, the cases in which the subject has been 'invited' to the station for questioning are by far the least protective of individual rights. Indeed, some of the decisions in this area are nothing short of amazing." Smith, supra note 4 , at 728.

12. Miranda, 384 U.S. at 444 . Where there is no custodial interrogation, however, statements made to the police are admissible into evidence regardless of whether Miranda warnings are given. The Miranda Court stressed that

[a]ny statement given freely and voluntarily without any compelling influences is, of course, admissible in evidence. The fundamental import of the privilege while an individual is in custody is not whether he is allowed to talk to the police without the benefit of warnings and counsel, but whether he can be interrogated. There is no requirement that police stop a person who enters a police station and states that he wishes to confess to a crime, or a person who calls the police to offer a confession or any other statement he desires to make. Volunteered statements of any kind are not barred by the Fifth Amendment and their admissibility is not affected by our holding today.

Id. at $\mathbf{4 7 8}$ (footnote omitted).

13. Courts have had much less difficulty in determining what constitutes "interrogation" than in deciding what constitutes "custody." Miranda itself clearly excludes "volunteered statements of any kind." 384 U.S. at 478. See generally Smith, supra note 4, at 702-06. 
commentators alike have suggested several different tests for determining whether an interrogation is custodial. These tests include objective and subjective formulations and a standard focusing on whether suspicion in a given case has centered on one particular individual.

The Miranda Court stated that "[b]y custodial interrogation, we mean questioning initiated by law enforcement officers after a person has been taken into custody or otherwise deprived of his freedom of action in any significant way." 14 That definition, however, was complicated by a footnote which seemingly equated "custodial interrogation" with "focus," as that term had been used in Escobedo v. Illinois. ${ }^{15}$ In Escobedo the Court held that the sixth amendment right to counsel attached when an "investigation is no longer a general inquiry into an unsolved crime but has begun to focus on a particular suspect . . ."16 However, as the cases that arose under Miranda have made clear, these two concepts are not in fact identical. Police may question an individual upon whom their suspicions have focused entirely without arresting that person or in any way interfering with his freedom of movement; the converse is also true.

Nonetheless, in an attempt to give some meaning to that language, a few courts used "focus" as the major factor in determining whether interrogation was custodial and, thus, whether Miranda warnings were required. ${ }^{17}$ In Beckwith v. United States, ${ }^{18}$ the Supreme Court rejected this position, holding that focus alone, without any other indicium of custody, does not trigger the necessity for Miranda warnings. ${ }^{19}$

14. 384 U.S. at 444 (footnote omitted).

15. 378 U.S. 478 (1964). "This is what we meant in Escobedo when we spoke of an investigation which had focused on an accused." Miranda, 384 U.S. at 444 n.4. Professor Kenneth W. Graham in his 1966 article referred to this as the "obfuscating footnote." Graham, supra note 4, at 114. That term has stuck and is widely used in the literature on the subject.

16. 378 U.S. at $490-91$.

17. In People v. Reed, 393 Mich. 342, 224 N.W.2d 867, cert. denied, 422 U.S. 1044 (1975), the Michigan Supreme Court held that where suspicion had focused on a suspect prior to questioning it was error to admit into evidence his responses to questions asked prior to his receiving Miranda warnings. See also People v. Ridley, 396 Mich. 603, 242 N.W.2d 402 (1976); People v. Martin, 78 Mich. App. 518, 521, 260 N.W.2d 869, 870 (1977). The Martin court stated: "Our research discloses no other state which has adopted the 'Focus Standard.' "Id. at 526 n.5, 260 N.W.2d at 873 n.5. However, at least two other jurisdictions could arguably be said to have adopted focus as an alternative test. In State v. Kalai, 56 Hawaii 366, 537 P.2d 8 (1975), the Hawaii Supreme Court intimated that Miranda warnings must be given prior to police questioning of a suspect upon whom suspicions had focused to the extent that police would have been justified in arresting him without a warrant. See State v. Patterson, - Haw. -, 581 P.2d 752, 754 (1978) (discussing Kalai). See text accompanying notes 128-34 infra for a discussion of the status of "focus" as a test in Pennsylvania.

18. 425 U.S. 341 (1976).

19. The Beckwith Court wrote:

Although the "focus" of the investigation may indeed have been on Beckwith at the time 
The great majority of jurisdictions and commentators had rejected the use of focus as the sole test of custodial interrogation even before Beckwith ${ }^{20}$ Most courts agreed that the proper test was an objective determination ${ }^{21}$ whether the defendant actually had been taken into custody, "or otherwise deprived of his freedom of action in any significant way,"22 although they varied in their precise formulations. Some

of the interview in the sense that it was his tax liability which was under scrutiny, he hardly found himself in the custodial situation described by the Miranda Court as the basis for its holding. Miranda implicitly defined "focus," for its purposes, as "questioning initiated by law enforcement officers after a person has been taken into custody or otherwise deprived of his freedom of action in any significant way."

425 U.S. at 347 (quoting Miranda, 384 U.S. at 444, and supplying emphasis).

For the reactions of Michigan courts to Beckwith, see People v. Robinson, 79 Mich. App. 145, 153 n.5, 261 N.W.2d 544, 548-49 n.5 (1977) (on the facts of the case the court found "no reason to reassess the position of the Michigan courts" in light of Beckwith); People v. Martin, 78 Mich. App. 518, 521-25, 260 N.W.2d 869, 870-72 (1977) (abandoning focus as a standard). For the reaction of the Pennsylvania courts, see text accompanying notes 128-34 infra; also see Commonwealth v. Anderson, _ Pa. Super. _, 385 A.2d 365, 372-73 n.13 (1978).

Interestingly, in a post-Beckwith case the New Mexico Court of Appeals stated that "[w]hen an investigation has focused on the accused he is entitled to the Miranda safeguards." State v. Wheeler, _ N.M. _, 583 P.2d 480, 481 (1978). However, the statement is merely dictum, since the statements suppressed in that case were made in response to police questioning when the defendant was undisputedly "not free to go," 583 P.2d at 481 , and by any test there was a custodial interrogation.

20. An influential and frequently cited case taking this position is United States v. Hall, 421 F.2d 540 (2d Cir. 1969), cert. denied, 397 U.S. 990 (1970), in which Judge Friendly wrote:

It is . . plain that "focus" alone does not trigger the need for Miranda warnings. As appears from ... Escobedo . . . custody as well as focus and other factors were essential to that decision. Under Miranda custody alone suffices . . . . We fail to perceive how one can reason from these two propositons to a conclusion that "focus" alone is enough to bring Miranda into play. The only possible basis for such an argument would be that, after limiting Miranda to custodial interrogation and defining this as "questioning initiated by law enforcement officers after a person has been taken into custody or otherwise deprived of his freedom of action in any significant way," . . . Chief Justice Warren dropped a footnote:

${ }^{4}$ This is what we meant in Escobedo when we spoke of an investigation which had focused on an accused.

While much dialectic skill has been expended on this footnote . . . the one thing that is undeniable is that the opinion said that focus means custody, not that custody means focus. As Professor Kamisar has put it, "Miranda's use of 'custodial interrogation' actually marks a fresh start in describing the point at which the Constitutional protections begin," . . -Fifth Amendment protections, that is.

Id. at 543 (quoting Miranda, 384 U.S. at $444 \&$ n.4, and Kamisar, supra note 4, at 339) (citations omitted).

21. This was Judge Friendly's position in Hall:

The test must be an objective one. Clearly the Court meant that something more than official interrogation must be shown. It is hard to suppose that suspicion alone was thought to constitute that something; almost all official interrogation of persons who later become criminal defendants stems from that very source. While the Court's language in Miranda was imprecise, doubtless deliberately so, it conveys a flavor of some affirmative action by the authorities other than police interrogation . . . . [I]n the absence of actual arrest something must be said or done by authorities, either in their manner of approach or in the tone or extent of their questioning, which indicates that they would not have heeded a request to depart or to allow the suspect to do so.

421 F.2d at 544-45 (emphasis in original).

22. Miranda, 384 U.S. at 444. 
spoke of determining "whether a reasonable man in defendant's position would have believed that he was not free to leave [or] . . . was 'in custody" ",23 others qualified this test by speaking of "a reasonable man, innocent of any crime"; ${ }^{24}$ and others attempted to construct multi-factor tests. ${ }^{25}$ Among the commmentators there has also been support for a more subjective test- one that would exclude from evidence answers to police questions by one who believed, even unreasonably, that his freedom of movement was restricted. ${ }^{26}$ This suggestion, however, has generally been rejected by the courts. ${ }^{27}$

23. People v. Aikens, 72 Cal. App. 3d Supp. 11, 15, 140 Cal. Rptr. 135, 137 (1977) (citing People v. Arnold, 66 Cal. 2d 438, 449, 426 P.2d 515, 522, 58 Cal. Rptr. 115, 122 (1967)). Numerous other decisions have employed this "reasonable man" test. See, e.g., Lowe v. United States, 407 F.2d 1391 (9th Cir. 1969); State v. Hatton, 116 Ariz. 142, 568 P.2d 1040 (1977); Myers v. State, 3 Md. App. 534, 240 A.2d 288 (1968); People v. P., 21 N.Y.2d 1, 233 N.E.2d 255, 286 N.Y.S.2d 225 (1967); Commonwealth v. Brown, 473 Pa. 562, 375 A.2d 1260 (1977). In New York, however, the test was later modified to that of the "reasonable innocent man" in People v. Yukl, 25 N.Y.2d 585, 256 N.E.2d 172, 307 N.Y.S.2d 857 (1969), cert. denied, 400 U.S. 851 (1970).

24. People v. Yukl, 25 N.Y.2d 585, 589, 256 N.E.2d 172, 174, 307 N.Y.S.2d 857, 860 (1969), cert. denied, 400 U.S. 851 (1970). Cases in other jurisdictions adopting this test include, e.g., Hicks v. United States, 382 F.2d 158 (D.C. Cir. 1967); People v. Wipfler, 68 Ill. 2d 158, 368 N.E.2d 870 (1977).

\section{For example,}

The Fifth Circuit employs a four-factor test to ascertain whether an interrogation occurred in a custodial context. These factors include: (1) whether probable cause to arrest had arisen, (2) whether the subjective intent of the officer conducting the interrogation was to hold the defendant, (3) whether the subjective belief of the defendant was that his freedom was significantly restricted, and (4) whether the investigation had focused on the defendant at the time of interrogation.

United States v. Warren, 578 F.2d 1058, 1071 (5th Cir. 1978) (citing numerous cases). While two of the factors identified are subjective in nature, the test seems to be applied with the goal of making an objective determination whether an interrogation is in fact custodial.

The Louisiana state courts have applied a similar test. See State v. Hodges, 349 So.2d 250, 255 (La. 1977), and cases cited therein. The Louisiana formulation stresses the objective nature of the test by speaking in terms of "statements or actions indicating" an intent or belief, $i d$. (quoting State v. Carey, 339 So.2d 804 (La. 1976)), rather than in terms of "subjective intent" or "subjective belief."

26. The argument for a subjective test is that "the person who honestly but unreasonably thinks he is under arrest has been subject to precisely the same custodial pressures as the person whose belief in this regard is reasonable." LaFave, "Street Encounters" and the Constitution: Terry, Sibron, Peters and Beyond, 67 MrCH. L. Rev. 39, 105 (1968); see Rothblatt \& Pitler, Police Interrogation: Warnings and Waivers-Where Do We Go From Here?, 42 Notre DAME LAW. 479, 485 (1967).

27. See, e.g., United States v. Hall, 421 F.2d 540 (2d Cir. 1969), cert. denied, 397 U.S. 990 (1970), in which Judge Friendly argued against any purely subjective test:

The Court could scarcely have intended the issue whether the person being interrogated had "been taken into custody or otherwise deprived of his liberty in any significant way" to be decided by swearing contests in which officers would regularly maintain their lack of intention to assert power over a suspect save when the circumstances would make such a claim absurd, and defendants would assert with equal regularity that they considered themselves to be significantly deprived of their liberty the minute officers began to inquire of them. Moreover, any formulation making the need for Miranda warnings depend upon how each individual being questioned perceived his situation would require a prescience neither the police nor anyone else possesses. On the other hand, a 
In conjunction with an objective test, focus of the investigation has often been identified (both before and after Beckwith) as one of the more significant factors in determining whether a given interrogation is custodial. ${ }^{28}$ Other factors often mentioned include the subjective intent of the officers to restrict the individual's freedom of movement, ${ }^{29}$ the subjective belief of the individual being questioned as to his freedom of movement, ${ }^{30}$ the existence of probable cause to arrest, ${ }^{31}$ the length and form of the questioning, ${ }^{32}$ and the place of interrogation. ${ }^{33}$

This last factor, place of questioning, was extremely important in the factual situations before the Court in Mirand $a^{34}$ and, whether clearly articulated or not, loomed large in the subsequent opinions of various courts as to the custodial or noncustodial nature of an interrogation. Writing for the Court in Miranda, Chief Justice Warren discussed at great length the particular danger of coercion associated with interrogation in a police-dominated atmosphere, ${ }^{35}$ of which the police station is the quintessential example. This emphasis led several early commentators to suggest that all police station interrogations are inherently custodial. ${ }^{36}$

standard hinging on the inner intentions of the police would fail to recognize Miranda's concern with the coercive effect of the "atmosphere" from the point of view of the person being questioned.

Id. at 544. See also Smith, supra note 4, at 710-14.

28. E.g., Alberti v. Estelle, 524 F.2d 1265, 1267 (5th Cir. 1975), and cases cited therein; People v. Herdan, 42 Cal. App. 3d 300, 306-07, 116 Cal. Rptr. 641, 645 (1974); State v. Hodges, 349 So.2d 250, 255 (La. 1977), and cases cited therein; see, e.g., People v. White, 69 Cal. 2d 751, 761, 446 P.2d 993, 997-98, 72 Cal. Rptr. 873, 878 (1968). While rejecting focus alone as a determinative test of custodial interrogation, Judge Friendly wrote in Hall:

This is not to say that the amount of information possessed by the police, and the consequent acuity of their "focus," is irrelevant. The more cause for believing the suspect committed the crime, the greater the tendency to bear down in interrogation and to create the kind of atmosphere of significant restraint that triggers Miranda, and vice versa. But this is simply one circumstance, to be weighed with all the others.

421 F.2d at 545.

29. See, e.g., Alberti v. Estelle, 524 F.2d 1265, 1267 (5th Cir. 1975), and cases cited therein; cf. State v Hodges, 349 So.2d 250, 255 (La. 1977) ("statements or actions by the police indicating an intention to hold or restrain [the person being questioned]").

30. See, e.g., Alberti v. Estelle, 524 F.2d 1265, 1267 (5th Cir. 1975); State v. Hodges, 249 So. 2d 250, 255 (La. 1977).

31. See cases cited at note 30 supra.

32. See, e.g., People v. Herdan, 42 Cal. App. 3d 300, 306-07, 116 Cal. Rptr. 641, 645 (1974), and cases cited therein.

33. See id; Commonwealth v. Haas, 77 Mass. Adv. Sh. 2212,,- 369 N.E.2d 692, 698 (1977).

34. In each of the four cases before the Court in Miranda "the defendant was questioned by police officers, detectives, or a prosecuting attorney in a room in which he was cut of from the outside world." 384 U.S. at 445. Indeed, in each case that room was located in a police station. Id. at 491-99.

35. Id. at $445-58$.

36. For example, Professor Kenneth W. Graham wrote in 1966: "If one assumes that the 
While subsequent cases showed little tendency to adopt such a sweeping rule of law with respect to police station interrogations, ${ }^{37}$ there was a definite correlation between the inherent coerciveness or intimidating atmosphere of the place of interrogation and the likelihood that courts would find a custodial interrogation to have taken place. $^{38}$ Custodial interrogation was found much more frequently where the questioning occurred in a police vehicle or a police station, sheriff's office or similar location. ${ }^{39}$ Thus, while neither focus on an individual suspect nor police station interrrogation alone necessarily constituted custodial interrogation for Miranda purposes, each was considered to be a strong indicium that the custody requirement had been met. However, the Supreme Court in Mathiason distinctly deemphasized the importance of these two factors.

\section{The MATHIASON Decision}

Both investigatory focus on the suspect and police station interrogation were present in Mathiason. The defendant had been suggested to the police as a burglary suspect. ${ }^{40}$ After several unsuccessful attempts to contact Mathiason, a state policeman left a note asking him to call because the officer would "like to discuss something" with him. Mathiason, a parolee, ${ }^{41}$ called the following day and agreed to meet the officer at a state patrol office. ${ }^{42}$ At the beginning of their interview,

interrogation requirement is met, it seems quite likely that all stationhouse interrogations will be held to be custodial in nature, whether the suspect came of his own accord, or at the suggestion of a parent, attorney, or military superior." Graham, supra note 4, at 82 . Graham based this conclusion on the experience of the California courts in applying Escobedo. "The California cases seem to support the position that all police station interrogation is impermissible." Id. 100-01. These decisions in many other respects successfully anticipated the Supreme Court's holdings in Miranda. Id. 62.

37. One exception involved the California Court of Appeals, which stated in dictum: "Usually, interrogation at a police station is deemed inherently coercive . . . People v. Herdan, 42 Cal. App. 3d 300, 307 n.9, 116 Cal. Rptr. 641, 645 n.9 (1974).

38. Annot., 31 A.L.R.3d 565, 576 (1970).

39. Id. 629-38.

40. "An officer of the State Police investigated a theft . . . He asked the lady of the house which has been burglarized if she suspected anyone. She replied that the defendant was the only one she could think of. The defendant was a parolee and a 'close associate' of her son." Mathiason, 429 U.S. at 493 (quoting 275 Or. at 3, 549 P.2d at 674). The United States Supreme Court quoted the Oregon Supreme Court's summary of the facts in the Mathiason case, 275 Or. at 3-4, 549 P.2d at 674, nearly verbatim. 429 U.S. at 493-94.

41. As a parolee, Mathiason might have believed more reasonably than another man that he had no real freedom to refuse to meet with the officer and answer questions. See note 57 infra for a discussion of the significance of status as a parolee in determining whether interrogation is custodial.

42. When Mathiason called, the officer asked where it would be convenient to meet. Mathiason expressed no preference, and the officer asked him to come down to the state patrol 
which took place behind closed doors, the officer told Mathiason that he was not under arrest but that the police suspected him of burglary and that his truthfulness would possibly be considered by the judge or prosecutor. He also falsely told Mathiason that his fingerprints had been found at the scene of the crime ${ }^{43}$ After sitting for a few minutes, the defendant said that he had taken the property. At that point he was advised of his Miranda rights, and the officer took a taped confession. At the close of the interview, which lasted about half an hour, Mathiason was allowed to leave.

The Oregon Supreme Court found the interrogation to have been custodial. ${ }^{44}$ It reasoned that under Miranda, "[t] $\mathrm{the}$ most compulsive feature of in-custody interrogation . . . is a person's belief that he cannot leave or break off the interrogation" 45 and that warnings are required "if the questioning takes place in a 'coercive environment." "46 By a four to three majority the Oregon court held that Mathiason's interrogation took place in a "coercive environment" since "[t]he parties were in the offices of the State police; they were alone behind closed doors; the officer informed the defendant he was a suspect in a theft and the authorities had evidence incriminating him in the crime; and the defendant was a parolee under supervision." 47 The court felt that "this evidence [was] not overcome by the evidence that the defendant came to the office in response to a request and was told he was not under arrest." 48 The court acknowledged that there was some contrary authority in other jurisdictions, ${ }^{49}$ but stated that "to hold that the confession in the present case was not obtained as a result of 'custodial interrogation' would be contrary to the rationale expressed in Miranda."50

office in an hour and a half. 429 U.S. at 493 (quoting 275 Or. at 3, 549 P.2d at 674).

43. 429 U.S. at 493 . In its opinion the Oregon Supreme Court did not mention that the information about the fingerprints was false. That fact appears in the decision of the Oregon Court of Appeals. State v. Mathiason, 22 Or. App. 494, 495, 539 P.2d 1122, 1123 (1975).

44. The trial court and the Oregon Court of Appeals had reached the opposite conclusion. 22 Or. App. at 494, 539 P.2d at 1122.

45. 275 Or. at 4,549 P.2d at 675 .

46. Id. (quoting State v. Travis, 250 Or. 213, 218, 441 P.2d 597, 599 (1968)). The court added: "We believe this is an accurate paraphrase of the idea expressed by the majority in Miranda when the Chief Justice wrote about 'the compelling atmosphere inherent in the process of in-custody interrogation." " 275 Or. at 4-5, 549 P.2d at 675 (quoting 384 U.S. at 478).

47. 275 Or. at 5, 549 P.2d at 675 .

48. Id.

49. The court cited People v. Yukl, 25 N.Y.2d 585, 256 N.E.2d 172, 307 N.Y.S.2d 857 (1969), cert. denied, 400 U.S. 851 (1970), but noted that "[t]hree judges violently dissented in that case." 275 Or. at 5, 549 P.2d at 675.

50. 275 Or. at 5, 549 P.2d at 675 . 
This judgment was reversed by the United States Supreme Court, which found that the Oregon court had "read Miranda too broadly ...."51 Finding that it was "clear from [the] facts that Mathiason was not in custody "or otherwise deprived of his freedom of action in any significant way," "52 the Court held that "[s]uch a noncustodial situation is not converted into one in which Miranda applies simply because a reviewing court concludes that, even in the absence of any formal arrest or restraint on freedom of movement, the questioning took place in a 'coercive environment." "53

The Court noted that all interviews of suspects by police officers have coercive aspects "simply by virtue of the fact that the police officer is part of a law enforcement system which may ultimately cause the suspect to be charged with a crime," but added that "police officers are not required to administer Miranda warnings to everyone whom they question." 54 The Court found no requirement of warnings "simply because the questioning takes place in the station house, or because the questioned person is one whom the police suspect." 55 Rather, "Miranda warnings are required only where there has been such a restriction on a person's freedom as to render him 'in custody.' It was that sort of coercive environment to which Miranda by its terms was made applicable, and to which it is limited." 56

Justices Brennan and Stevens dissented from the summary dispostion of Mathiason, ${ }^{57}$ and Justice Marshall, for two reasons, dissented on
51. 429 U.S. at 493.
52. Id. at 495 (quoting Miranda, 384 U.S. at 444).
53. 429 U.S. at 495.
54. Id.
55. Id.
56. Id. (emphasis in original).

57. Mathiason was decided without full argument. In addition, the record of the case had not been transmitted to the Supreme Court. Thus, the Court's knowledge of the facts was "limited to the information contained in the petition and in the opinions of the state courts." 429 U.S. at 497 n.2 (Marshall, J., dissenting).

Justice Stevens in his dissent stated that "the issues presented by this case are too important to be decided summarily." Id. at 499.

Of particular importance is the fact that the respondent was on parole at the time of his interrogation in the police station. This fact lends support to inconsistent conclusions.

On the one hand, the State surely has greater power to question a parolee about his activities than to question someone else. Moreover, as a practical matter, it seems unlikely that a Miranda warning would have much effect on a parolee's choice between silence and responding to police interrogation. Arguably, therefore, Miranda warnings are entirely inappropriate in the parole context.

On the other hand, a parolee is technically in legal custody continuously until his sentence has been served. Therefore, if a formalistic analysis of the custody question is to determine when the Miranda warning is necessary, a parolee should always be warned. Moreover, Miranda teaches that even if a suspect is not in custody, warnings are necessary if he is "otherwise deprived of his freedom of action in any significant 
the merits. First, he thought that the meager record before the Court ${ }^{58}$ was inadequate to sustain a factual determination that Mathiason had not "been taken into custody or otherwise deprived of his freedom of action in any significant way."59 Justice Marshall's second ground for disagreement was more fundamental: "I cannot agree with the Court's conclusion that if respondent were not in custody no warnings were required. I recognize that Miranda is limited to custodial interrogations, but that is because, as we noted last term, the facts in the Miranda cases raised only this 'narrow issue." "60 But, Justice Marshall opined, "[t]he rationale of Miranda . . . is not so easily cabined."

Justice Marshall pointed out that Miranda required warnings "to 'combat' a situation in which there are 'inherently compelling pressures which work to undermine the individual's will to resist and to compel him to speak where he would not otherwise do so freely." "62 $\mathrm{He}$ con-

way." If a parolee being questioned in a police station is not described by that language, today's decision qualifies that part of Miranda to some extent.

Id. at 499-500 (Stevens, J., dissenting) (quoting Miranda, 384 U.S. at 444); see Jones v. Cunningham, 371 U.S. 236 (1963), in which a parolee was held to be "in custody" so as to give the federal courts jurisdiction to hear his petition for a writ of habeas corpus.

One post-Mathiason case in which no requirement of Miranda warnings was found when a parolee was questioned is In re Richard T., 79 Cal. App. 3d 382, 144 Cal. Rptr. 856 (1978). The juvenile parolee's parole officer suspected him of a parole violation and asked the youth to accompany him to the parole office to investigate the matter. On route the officer questioned the youth about the alleged violation-possession of a gun-without giving him Miranda warnings. It later developed that the gun was stolen, and the parolee was charged with receiving stolen property. The Court held that the youth's answers to the officer's questioning were admissible: "In the context of this case we hold that there was no custodial interrogation as the term is defined in Miranda . . . . [A]lthough parolees are entitled to the protections afforded by the Miranda warnings, not every contact arising out of the parole relationship requires such warning." Id. at 389 , 144 Cal. Rptr. at 860 (citations omitted).

Faced with the somewhat analogous question of whether a person released on bail is "in custody" for Miranda purposes, two panels of the Illinois Court of Appeals have reached seemingly opposite conclusions. In People v. Petty, 54 Ill. App. 3d 1044, 370 N.E.2d 553 (1977), the court held that Miranda warnings were required when a suspect who was out on bail was given a polygraph test:

Defendant . . . had been formally charged with a crime and arrested prior to the time of

his examination. Any freedom to depart . . . was a result only of his admission to bail.

The questioning was related to an accusatory rather than investigatory stage of proceed-

ings; hence the protection of Miranda warnings was required.

Id. at 1049, 370 N.E.2d at 557. In Petty, the defendant had received the warnings and was found to have waived his rights under them. In People v. Roberson, 46 Ill. App. 3d 750, 361 N.E.2d 116 (1977), a policeman questioned a suspect who had just been released on bail, eliciting an incriminating statement about another crime. Relying on Mathiason the court held the statement admissible "for the reason that [defendant] was not in custody at the time." $I d$. at 755, 361 N.E.2d at 120.

58. See note 57 supra.

59. 429 U.S. at 496 (Marshall, J., dissenting) (quoting Miranda, 384 U.S. at 444).

60. Id. at 497 (Marshall, J., dissenting) (citing Beckwith, 425 U.S. at 345).

61. Id. at 497 (Marshall, J., dissenting).

62. Id. at 497-98 (Marshall, J., dissenting) (quoting Miranda, 384 U.S. at 467). 
cluded:

[F]aithfulness to Miranda requires us to distinguish situations that resemble the "coercive aspects" of custodial interrogation from those that more nearly resemble "[g]eneral on the scene questioning . . . of citizens in the fact finding process" which Miranda states usually can take place without warnings. . . .

In my view, even if respondent were not in custody, the coercive elements in the instant case were so pervasive as to require Mirandatype warnings. ... I therefore agree with the Oregon Supreme Court that to excuse the absence of warnings given [on the facts of this case] is "contrary to the rationale expressed in Miranda."63

Justice Marshall's dissent, like the opinion of the Oregon Supreme Court, reflects a conviction that the individual who "voluntarily" submits to a "request" to answer questions (and who in a technical sense may be "free" to walk out of the station at any time) is in reality subject to much the same coercive atmosphere and tactics as the person actually placed under arrest or otherwise restrained. Under this view, police questioning of an individual in a "coercive environment" violates the "complex of values" upon which the privilege against self-incrimination is founded ${ }^{64}$ regardless of whether that questioning is "custo-

63. Id. at 498 (Marshall, J., dissenting) (quoting Miranda, 384 U.S. at 477, and 275 Or. at 5, 549 P.2d at 675). Justice Marshall identified the following as "coercive elements" in Mathiason:

Respondent was interrogated in "privacy" and in "unfamiliar surroundings," factors on which Miranda places great stress. [Miranda, 384 U.S.] at 449-50; see also Beckwith v. United States, [425 U.S.] at 346 n.7. The investigation had focused on respondent. And respondent was subjected to some of the "deceptive stratagems," Miranda v. Arizona, [384 U.S.] at 455, which called forth the Miranda decision.

429 U.S. at 498 (Marshall, J., dissenting). The majority rejected reliance upon a "coercive environment" or upon the fact that the investigation had focused on the defendant in establishing that there had been a custodial interrogation. See text accompanying notes 53-56 supra. With respect to the officer's false statement concerning fingerprints (Marshall's last "coercive element"), the majority wrote: "Whatever relevance this fact may have to other issues in the case, it has nothing to do with whether respondent was in custody for purposes of the Miranda rule." 429 U.S. at 495 96.

64. Miranda, 384 U.S. at 460 (citing Murphy v. Waterfront Comm'n, 378 U.S. 52, $55-57$ n.5 (1964), and Tehan v. Shott, 382 U.S. 406, 414-15 n.12 (1966)).

In the case of $I n$ re Gault, 387 U.S. 1 (1967), in which the privilege against self-incrimination was extended to juvenile proceedings, Justice Fortas wrote:

The roots of the privilege [against self-incrimination] . . tap the basic stream of religious and political principle because the privilege reflects the limits of the individual's attornment to the state and-in a philosophical sense-insists upon the equality of the individual and the state. . . . [T] he privilege has a broader and deeper thrust than the rule which prevents the use of confessions which are the products of coercion because coercion is thought to carry with it the danger of unreliability. One of its purposes is to prevent the state, whether by force or by psychological domination, from overcoming the mind and will of the person under investigation and depriving him of the freedom to decide whether to assist the state in securing his conviction.

Id. at 47 . Under such an analysis it would not seem that the state should be permitted to employ that "psychological domination" in a coercive but noncustodial situation any more than in a custodial one. 
dial" in a narrow sense of the word.

The majority opinion, however, emphasized that the psychological compulsion of an intimidating atmosphere, even when coupled with an additional coercive factor such as the individual's knowledge that he is the prime suspect in a police investigation, is not sufficient to render an interrogation "custodial." The majority implied that only an actual arrest or some definite physical restraint on a person's movements will constitute "custody or other significant deprivation of freedom of action."65 This emphasis on actual, physical custody caused Justice Marshall to add a footnote to his dissent stating: "I trust that today's decision does not suggest that police officers can circumvent Miranda by deliberately postponing the official 'arrest' and the giving of Miranda warnings until the necessary incriminating statements have been obtained."

\section{Developments Since the Mathiason Decision}

Shortly after it was handed down, Mathiason, with its emphasis on actual, physical custody and its denigration of "coercive atmosphere" as a factor in determining whether police interrogations are custodial, was widely viewed as a significant contraction of the rights of the accused. ${ }^{67}$ It might well have been expected that Mathiason would herald a new era in which the number of situations requiring Miranda warnings would be greatly reduced. This is especially so in light of the strong opposition expressed by many judges ${ }^{68}$ and others ${ }^{69}$ to the Miranda doctrine at the time it was announced. Yet, although many courts have had occasion to consider the questions presented by Mathiason, few decisions have seized upon Mathiason as a justification for further restrictions on the scope of Miranda. In fact, some courts have confined Mathiason narrowly to its facts and have refused to ap-

65. See text accompanying note 14 supra.

66. 429 U.S. at 499 n.5 (Marshall, J., dissenting).

67. The director of the American Civil Liberties Union was quoted in the New York Times as saying that Mathiason "very substantially negates the Miranda decision." N.Y. Times, Jan. 26, 1977, § A, at 14, col. 4. Another commentator opined that Mathiason "[limited] Miranda's application and [gave] police investigators an essentially free hand in interrogation." Keefe, Confessions, Admissions and the Recent Curtailment of the Fifth Amendment Protection, 51 CoNN. B.J. 266, 282 (1977). Student commentators are also in substantial agreement. See authorities listed at note 7 supra.

68. "[O]n the basis of four lively workshop sessions . . . with the Chief Justices of the States at the [1966] Meeting of the Conference of Chief Justices . . . , I would have to say they were overwhelmingly opposed to the recent confession rulings." Kamisar, A Dissent from the Miranda Dissents: Some Comments on the "New" Fifih Amendment and the Old "Voluntariness" Test, 65 MICH. L. REV. 59, 59 n.3 (1966).

69. For a sample of public reaction, see TIME, June 24, 1966, at 53-54. 
ply its holding in similar situations, despite the exhortation of prosecutors.

In most of the cases in which Mathiason has been held controlling, the fact situations have been analogous to that in Mathiason itself. A number involved individuals who had, upon police request, presented themselves at the stationhouse for questioning, ${ }^{70}$ taken a polygraph test, ${ }^{71}$ or had a photograph ${ }^{72}$ or fingerprints ${ }^{73}$ taken. Similarly, in some cases the defendant heard that the police were looking for him and voluntarily appeared at the station, ${ }^{74}$ or knew that he was under suspicion and appeared without any police prompting to make self-serving statements. $^{75}$

70. For example, in People v. Wipfler, 68 Ill. 2d 158, 368 N.E.2d 870 (1977), a detective called at the home of the 18-year-old defendant and told the youth's mother that he wanted to speak with her son about some burglaries. She said that she would tell the youth to go to the police station after school. There two officers questioned him behind closed doors, eliciting a confession. The Illinois Supreme Court, after reviewing Mathiason, concluded that Wipfler had not been subjected to custodial interrogation:

[T] he record supports the interpretation that defendant was not compelled to come to the station, much less to answer questions, and that, regardless of defendant's subjective beliefs, he was not, and would not have been, forbidden to leave. The officers testified that he would have been permitted to leave because "there was nothing to hold him for." In short, when the situation is viewed objectively, defendant was not in custody or otherwise deprived of his freedom of action in any significant way, and so Miranda warnings were not required at the outset of the interrogation.

Id. at 170, 368 N.E.2d at $874-75$ (citation omitted). However, two justices vigorously dissented: The constitutional rights which Miranda was designed to protect are so important that their effective exercise should not depend on the type of judicial hairsplitting present in this and similar cases. ... It would be remarkable indeed if under [these] circumstances an 18-year-old high school student reached any conclusion other than he was in custody and that any attempt to leave would be unsuccessful.

Id. at 175-76, 368 N.E.2d at 877 (Goldenhersh, J., dissenting).

In People v. Ellis, 91 Misc. 2d 28, 397 N.Y.S.2d 541 (Sup. Ct. 1977), a woman had been found dead in a hotel bathroom under highly suspicious circumstances, although the death was not initially listed as a homicide. A police detective left a message for the defendant to contact him. Ellis appeared at the police station and, after answering some initial questions, voluntarily agreed to accompany the detectives to a nearby precinct station where they could continue the interview privately. The story he gave to the detectives was wholly exculpatory, but was contradicted in important respects by the medical evidence. Analogizing the factual situation to that in Mathiason, the court found that the interrogation was not custodial.

Other cases in this category include: People v. Liccione, 63 App. Div. 2d 305, 407 N.Y.S.2d 753 (1978); State v. Street, 572 P.2d 577 (Okla. Crim. App. 1977); State v. Johnson, _ R.I. _, 383 A.2d 1012 (1978); State v. Neeley, _ S.C. _, 244 S.E.2d 522 (1978). Cf. State v. Martin, 294 N.C. 702,242 S.E.2d 762 (1978) (defendant at police request left his home and came out to a patrol car to answer questions). See also United States v. Kilbourne, 559 F.2d 1263 (4th Cir.), cert. denied, 434 U.S. 873 (1977).

71. People v. Varney, 58 Ill. App. 3d 70, 373 N.E.2d 1033 (1978); People v. McCue, 48 Ill. App. 3d 41, 362 N.E.2d 760 (1977).

72. Starkey v. Wyrick, 555 F.2d 1352 (8th Cir.), cert. denied, 434 U.S. 927 (1977).

73. Hancock v. Estelle, 558 F.2d 786 (5th Cir. 1977); Moore v. State, 344 So.2d 731 (Miss. 1977).

74. E.g., United States v. Shelly, 573 F.2d 971 (7th Cir. 1978).

75. State v. Falk, 17 Wash. App. 905,567 P.2d 235 (1977). 
Some courts have used Mathiason as general support for findings that police interrogation claimed by defendants to be custodial was in fact "general on-the-scene questioning" permissible without Miranda warnings. ${ }^{76}$ The Supreme Court in Miranda exempted from the requirement of warnings "[g]eneral on-the-scene questioning as to facts surrounding a crime or other general questioning of citizens in the factfinding process . .."77 Differentiating this type of questioning from

According to the officer the defendant came to the station house on his own initiative, not once but twice, after his release on bond. The information was not a response to interrogation but was offered in an apparent attempt to gain some personal advantage. ... The situation here was closely akin to that in Oregon v. Mathiason . . . , which we believe is determinative of this issue.

Id. at 908-09, 567 P.2d at 238.

While the Falk court relied on Mathiason, there is strong support for its conclusion in Miranda itself. See 384 U.S. at 478 , quoted at note 12 supra.

76. E.g., State v. Hilliard, 89 Wash. 2d 430, 573 P.2d 22 (1977). In that case the defendant was questioned at the scene of an assault. He was under such suspicion that the police later testified that they would not have allowed him to leave without accounting for his presence. However, the defendant was told that if his story checked out he would be allowed to go. Citing Mathiason, the court held that "[t]he questioning of defendant was not a custodial interrogation. Mere suspicion, before the facts are reasonably developed, is not enough to turn the questioning into a custodial interrogation." Id. at 436, 573 P.2d at 26. The Washington Court of Appeals has since commented:

As we read Hilliord, it retreats slightly from the principle enunciated in State $v$. Creach, 77 Wn.2d 194, 461 P.2d 329 (1969) that the interrogation must be under circumstances where there is absolutely no pressure from police presence and that the subject must be free to leave to any time. We feel that this retreat is a recognition of the reality that it would be poor social policy to require the police to walk away from a situation such as existed in Hilliard simply because there was as yet no probable cause to arrest, although the circumstances were suspicious and required investigation.

State v. Webster, 20 Wash. App. 128, _, 579 P.2d 985, 989 (1978).

Similarly, in Adkins v. Commonwealth, _ Va. _, 243 S.E.2d 205 (1978), the defendant was stopped by police detectives and questioned concerning the ownership of a stereo and a television set in his car. The defendant gave conflicting stories about the ownership of the items and waited with the detectives for an unspecified length of time while they tried to determine whether the items were stolen. Applying Mathiason, the court held: "The fact that the defendant's questioning by the police concerning the ownership of the items may have caused him to feel that he was deprived of his right to leave the scene does not require the Miranda warnings to be given." 243 S.E.2d at 208. See State v. Mitchell, 35 Or. App. 809, 583 P.2d 14 (1978), for another case similar to Hilliard and Adkins.

State v. Ousley, _ Minn. _, 254 N.W.2d 73 (1977), involved a woman whose young child died in a bathtub drowning. She was subsequently charged with aggravated assault for a beating that she allegedly gave the child a week earlier and sought unsuccessfully to exclude statements she made to an investigating officer on the day of the drowning. The Minnesota court wrote:

If there were any doubts about the correctness of the [trial] court's ruling, and we do not believe there were, those doubts were erased by the United States Supreme Court's recent decision in Oregon $v$. Mathiason . . . . There the court emphasized that the test in determining the need for a Miranda warning is not whether the interrogation has coercive aspects to it or whether the person being interrogated is a suspect, but whether the person is in custody or otherwise deprived of his freedom of action in any significant way. Here, defendant was not in custody nor was her freedom of action restricted in any signficant way when the investigating officer questioned her at home.

254 N.W.2d at $73-74$.

77. 384 U.S. at 477 . Cases applying this "general on-the-scene questioning" rule are col- 
custodial interrogation poses some problems, ${ }^{78}$ especially since the courts have acknowledged that on-the-scene questioning not requiring Miranda warnings often involves an element of detention. ${ }^{79}$ While Mathiason did not involve on-the-scene questioning, courts have used its restrictive definition of custodial interrogation to buttress their conclusions that certain types of on-the-scene questioning are not custodial. $^{80}$

Mathiason has also been cited as authority by courts refusing to extend the requirement of Miranda warnings to such contexts as the testimony of a witness at the trial of another, ${ }^{81}$ an investigatory interview by postal inspectors, ${ }^{82}$ police questioning of hospital patients, ${ }^{83} \mathrm{a}$ coroner's interview with a mother he suspected of causing her child's death $^{84}$ and investigatory interviews into welfare fraud ${ }^{85}$ and child

lected in Annot., 31 A.L.R.3d $565 \$ 3$ (1970 \& Supp. 1978). By analogy, courts have held that routine traffic stops (e.g., Lowe v. United States, 407 F.2d 1391 (9th Cir. 1969); Ford v. United States, 376 A.2d 439 (D.C. App. 1977)), border patrol checks for entering aliens (Williams v. United States, 381 F.2d 20 (9th Cir. 1967)), customs searches (United States v. Thompson, 475 F.2d 1359 (5th Cir. 1973)), and Coast Guard inspections of American vessels on the high seas (United States v. Warren, 578 F.2d 1058 (5th Cir. 1978)) do not, without more, create custodial situations.

78. See generally Kamisar, supra note 4, at 360-82; LaFave, supra note 26; Smith, supra note 4 , at 714-18.

79. E.g., United States v. Clark, 425 F.2d 827, 832 (3d Cir.), cert. denied, 400 U.S. 820 (1970); Allen v. United States, 390 F.2d 476, 479 (D.C. Cir. 1968).

80. See note 76 supra.

81. People v. Lamorie, _ Colo. _, 560 P.2d 85 (1977). In that case the defendant had been subpoenaed as a witness, but on the day of trial was given a flat option not to testify at all. However, he insisted on testifying even after being told of his right to exercise the privilege against self-incrimination. The defendant later sought to have the testimonial admissions he had made at the trial suppressed when he was charged with perjury and attempted burglary. The court held that "this was not the sort of 'custodial interrogation' which was intended to trigger the full complement of protections outlined in Miranda v. Arizona . . ." 560 P.2d at 87. While principal reliance was placed upon United States v. Mandujano, 425 U.S. 564 (1976), Mathiason was cited for the proposition that "mere existence of incidential coercive aspect and police suspicion does not constitute 'custodial interrogation." " 560 P.2d at 87.

82. United States v. Lewis, 556 F.2d 446 (6th Cir.), cert. denied, 434 U.S. 863 (1977). Although the investigation triggered criminal proceedings and had focused on the defendant, there was no custodial interrogation since "[a]s in Mathiason, the meeting was mutually arranged and took place at a Government office after the [defendant] voluntarily presented himself there." 556 F.2d at 449 .

83. People v. Clark, 55 Ill. App. 3d 496, 371 N.E.2d 33 (1977); State v. Overstreet, 551 S.W.2d 621 (Mo. 1977); cf. State v. Franklin, 281 Md. 52, 58, 375 A.2d 1116, 1120 (1977), cert. denied, 434 U.S. 1018 (1978) (court assumed that hospital interview of wounded attempted-robbery suspect was custodial interrogation, adding "But see Oregon v. Mathiason ... .").

84. Commonwealth v. Anderson, _ Pa. Super. _, 385 A.2d 365 (1978).

85. Doe v. Chang, 58 Hawaii 94, 564 P.2d 1271 (1977). The plaintiff welfare recipients sought to enjoin any such interviews from being conducted without Miranda warnings. The court noted that the plaintiffs alleged no deprivation of their freedom of action "other than the constraint imposed by their assumption that cooperation with the questioners was a condition of continued welfare benefits, nor have they alleged that they were informed that failure to provide 
abuse $^{86}$ conducted by social workers. These cases are ones in which, even before Mathiason, it is unlikely that the defendants would have been able to persuade courts that there had been a custodial interrogation within the meaning of Miranda. Given the restrictive view of custodial interrogation espoused by the Mathiason Court, it is hardly surprising that other courts are not finding a need for Miranda warnings in contexts often far removed from the typical police interrogation.

What is perhaps surprising is that the state and lower federal courts have shown little or no tendency to use Mathiason as a vehicle for further contraction of Miranda rights by applying it outside its own factual situation to cases in which Miranda warnings would previously have been thought to be required. ${ }^{87}$ Indeed, sometimes over vigorous dissents, some courts have continued to find a need for Miranda warnings in cases in which Mathiason arguably dictates the opposite result.

A prime example of such a case is United States $v$. DiGiacomo. ${ }^{88}$ In that case, two Secret Service agents approached the defendant and a companion in a restaurant parking lot. They identified themselves and said they wanted to talk about some counterfeit money that

such cooperation would result in any disadvantage to them." 564 P.2d at 1273-74. Mathiason was quoted at some length to support the court's conclusion that the Miranda rule was not applicable. Id.

86. People v. Easter, 90 Misc. 2 d 748, 395 N.Y.S.2d 926 (County Ct. 1977). The defendant in that case, aware that he was suspected of child abuse, had actually sought out the social worker.

87. One possible example of such a case, however, is Barfield v. Alabama, 552 F.2d 1114 (5th Cir. 1977). Bertha Barfield had been named to the police as a possible murder suspect. She came voluntarily to the police station for an interview, but was allegedly told that she could not leave. The Fifth Circuit panel observed:

The force and effect of such a statement, assuming it was made . . . is diminished by the

fact that Barfield was left alone, her departure unimpeded by physical restraints or the

presence of other officers. When viewed in that light, [the officer's] alleged statement to

Barfield that she remain in the office seems more in the nature of a precatory request

than a command.

Id. at 1118 (footnote omitted). The court cited United States v. Brunson, 549 F.2d 348, 357 nn.1213 (5th Cir.) cert. denied, 434 U.S. 842 (1977). as authority for this conclusion. The court held that the facts of the interrogation were so close to those in Mathiason as to render that case controlling. Although this would seem to indicate a very restrictive view of what constitutes custodial interrogation, more restrictive than would be justified by Mathiason, it should be noted that Barfield's incriminating statement was not actually made in response to interrogation by an officer; rather, as the officer returned to the room in which he had left the defendant alone, he overheard her make an inculpatory remark while talking to herself in a distraught manner.

Another decision that might possibly be read as going beyond Mathiason is United States v. Long Soldier, 562 F.2d 601 (8th Cir. 1977), where the court stated: "Defendant's statements . . . were admissible under the rationale of Oregon $v$. Mathiason . . . , where the Supreme Court held that, absent a custodial arrest, interrogation of a suspect does not require Miranda warnings." Id. at $603 \mathrm{n} .1$ (emphasis added). The superficial rendition of the facts in that case makes it impossible to tell whether the court's reference to "custodial arrest" goes beyond the Mathiason holding to require an actual arrest, or is merely a slip.

88. 579 F.2d 1211 (10th Cir. 1978). 
DiGiacomo had spent. DiGiacomo agreed to wait with them until two other agents arrived. At the suppression hearing ${ }^{89}$ the first two agents testified that they, together with DiGiacomo and and his companion, waited together in a group for approximately five minutes until the other agents arrived. They further testified that they asked no questions at that time. The other agents, however, testified that when they arrived DiGiacomo and his companion were separated, with each attended by one of the agents already present. One of the late arrivals also testified that when he had been summoned to come to the parking lot, one of the other agents had said that the defendant was already being interviewed.

After the arrival of the second set of agents DiGiacomo was given an incomplete advisement of his rights. ${ }^{90} \mathrm{He}$ allowed the agents to check the currency he was carrying. A counterfeit bill was found, and the agents informed DiGiacomo of the seriousness of the matter and told him it would be to his advantage to tell the whole truth. He then made an inculpatory statement to one of the agents. At some uncertain point during the conversation an agent told DiGiacomo that they could arrest him that night or he could cooperate, answer questions and appear voluntarily at the Secret Service office the following morning.

The trial court suppressed the defendant's statements and the government appealed, relying upon Mathiason to argue that the defendant was not entitled to Miranda warnings because he had not been in custody during the interrogation. The Tenth Circuit Court of Appeals distinguished Mathiason on its facts and held that "[t]he trial court was justified in holding that the agents' actions in the parking lot were "functionally equivalent to an arrest." "91

The court's holding and its distinguishing of Mathiason prompted a vigorous dissent by Judge Barrett:

In my view, [the parking lot] encounter was such that the trial court was clearly erroneous in finding that the ensuing interrogation of DiGiacomo was "custodial" within the meaning of Miranda $v$.

89. The only evidence taken at the suppression hearing was the testimony of the four Secret Service agents. Id. at 1212 .

90. There was conflicting testimony as to the content of the warnings given the defendant, $i d$. at 1212-13, but the court upheld a trial court determination "that the government failed to prove by a preponderance of the evidence that defendant was advised of his right to appointed counsel and his right to terminate questioning anytime." Id. at 1214.

91. Id. at 1214. The court went on to find "ample support in the record" for the lower court's determination that DiGiacomo's appearance at the Secret Service office the following day was not voluntary and that "proper Miranda warnings were necessary." Id. The court determined that proper warnings had been given at that time, but that the defendant had not waived his right to counsel under them. Accordingly, further incriminating statements he made at that time were also suppressed. Id. at 1215 . 
Arizona . . , in light of the facts and circumstances related in Oregon v. Mathiason....

It is clear to me that the facts of the instant case fit within the "four corners" of [Mathiason]. There is no evidence in the record before us that the Secret Service agents . . . did other than request that he remain in the parking lot until the other two agents arrived. ... [T] here is nothing in the record evidencing that DiGiacomo was "deprived of his freedom of action in any significant way." And any reliance on "coercive environment" is dispelled by Mathiason. ${ }^{92}$

The majority opinion in DiGiacomo is in fact difficult to reconcile with Mathiason. Comparing the factual situations, there is no easily apparent reason why Nicholas DiGiacomo should have been entitled to Miranda warnings if Carl Mathiason was not. The Miranda warnings were designed to combat what were perceived as "inherently compelling pressures" in custodial interrogation-pressures which endangered the privilege against self-incrimination. ${ }^{93}$ It is difficult to see how the interrogation of DiGiacomo was any more "custodial" than that of Mathiason, and the "inherently compelling pressures" on DiGiacomo were arguably less. Both men were aware that they were objects of investigations by the authorities, and both had been advised to cooperate, but Mathiason was questioned alone in the seclusion of a police station while DiGiacomo was accompanied by a friend and in a public place.

The DiGiacomo court was not at -all precise in distinguishing Mathiason; it merely summarized the facts of the two cases without indicating the differences which it found to be crucial. ${ }^{94}$ Apparently, the court viewed Mathiason as applicable only to a narrow class of cases involving suspects who voluntarily present themselves for questioning in response to a police request ${ }^{95}$ and as excluding all others to which the Mathiason rationale might otherwise seem applicable.

There are other cases in which the courts' attempts to distinguish Mathiason seem strained. In Commonwealth v. Brown, ${ }^{96}$ the defendant accompanied police officers to the station, at their request, after specifically being told that he was not under arrest. He was questioned at length and returned to the station the following day, again accompa-

92. Id. at 1216-17 (Barrett, J., dissenting) (emphasis added). The dissent went on to add: "This approach applies with equal force to DiGiacomo's presence in the Secret Service agents' office on the morning of July 27." Id. at 1217.

93. Miranda, 384 U.S. at 467.

94. 579 F.2d at 1214.

95. Since DiGiacomo himself had voluntarily remained in the parking lot for questioning at the agents' request, id. at 1212 , the court may also have found some significance in the fact that, unlike Mathiason, DiGiacomo was not specifically told that he was "not under arrest."

96. 473 Pa. 562, 375 A.2d 1260 (1977). 
nied by officers and at their request. The Pennsylvania Supreme Court, in finding a custodial interrogation, distinguished Mathiason on the grounds that although the defendant had been requested rather than ordered to come to the police station, he "was not given any option as to the time and place of questioning and was accompanied by police officers both times he went to the Public Safety building."97

It is true that in Mathiason the defendant was given such an option rather than being asked, for example, "Would you please come down to the station tomorrow to answer a few questions?" It is also true that the officer did not walk to the station with Mathiason. Yet neither of those factors seems to have been crucial to the rationale of the Mathiason decision. ${ }^{98}$ The Brown court also noted that the appellant was questioned repeatedly over two days and contrasted this with the much briefer interrogation in Mathiason. ${ }^{99}$ Mathiason, however, was not premised upon the relative brevity of the interrogation in that case. The Pennsylvania court in Brown seems to have taken the position that the cumulative effect of these relatively minor deviations from the Mathiason facts was to require Miranda warnings. ${ }^{100}$ In basic outline, however, Mathiason and Brown presented similar factual situations, differing in degree rather than in kind. ${ }^{101}$

Another case in which a court has found custodial interrogation despite the insistence of the prosecution that Mathiason should control is Commonwealth v. Haas. ${ }^{102}$ In that case, the defendant's wife and children were found murdered in their home while he was at work. There was at least some evidence pointing toward the defendant's involvement in the crime, ${ }^{103}$ and the chief of police instructed his men

97. Id. at 572 n.6, 375 A.2d at 1265 n.6.

98. In State v. Neeley, _ S.C. —, 244 S.E.2d 522 (1978), the defendant was accompanied by officers when he agreed to go to the station for questioning. The South Carolina Supreme Court had no diffculty applying Mathiason to that situation. 244 S.E.2d at 526-27. The same was true in Malone v. State, 361 So. 2 d 674 (Ala. Crim. App. 1978).

99. $473 \mathrm{~Pa}$. at 572 n.6, 375 A.2d at 1265 n.6.

100. The court found the interrogations in the two cases to be "in marked contrast" when taken as a whole, id, and added that

the mere fact that appellant, like Mathiason, was told he was not under arrest does not mean that appellent was never subjected to custodial interrogation . . . . Nor can we conclude that the questioning of appellant was not custodial interrogation simply beId. cause the police requested that appellant come to the Public Safety Building.

101. In both cases suspects agreed to submit to police station questioning at police request. In both they were specifically told they were not under arrest.

102. _ Mass. _, 369 N.E.2d 692 (1977).

103. The front door of the house was ajar with a key in the lock; otherwise the house was in order. The medical examiner informed the police that the murder victims had died between 3 and 5 a.m. A man working regular hours would generally be expected to be home at that time. In addition, when Haas first called the police from work, to ask them to check the house, he stated 
not to let the defendant into his house, but rather to bring him to the station and inform him of the deaths there. The house had been sealed to all but police personnel. At the suppression hearing the Commonwealth argued that humanitarian motive had prompted the police to bar Haas from the murder scene. There was further testimony that Haas had voluntarily accompanied the police to the station, where his response to a police question proved incriminating ${ }^{104}$ and prompted his arrest.

The court's rationale for holding that the questioning of Haas was custodial $^{105}$ is interesting in light of Mathiason, upon which the Commonwealth had relied. The court seemed to advance the "coercive environment" argument that the Supreme Court had rejected in Mathiason:

[T] he questioning took place in the environs of the . . police station by conscious decision of the police. . . . The station house atmosphere is generally most conducive to successful interrogation because the investigator "possess[es] all the advantages." . . . [T] he Commonwealth's argument that the police were motivated by humanitarian concerns does not detract from the atmosphere which the law often recognizes as coercive nor does it obviate the need for Miranda warnings. ${ }^{106}$

That the investigation had begun to focus on Haas and that he was not allowed to enter his home were among other facts listed in support of the court's finding of custodial interrogation.

The court's observation that "we need not decide whether the police's action in refusing Haas entrance into his own home in the interest of preserving the crime scene deprived Haas of his freedom of action in a significant way" 107 is also notable, since there appears to be no indication that Haas's freedom of action was interfered with at any other

that he had received an anonymous phone call to the effect that "black and white don't mix." A sign bearing an identical slogan was in fact found at the murder scene.

104. Haas told the police he had left home at $6: 30$ a.m., considerably later than the time of death estimated by the medical examiner.

105. Chief Justice Hennessey's partial dissent seems to have concurred with the majority on this point. See 369 N.E.2d at 706-07 (Hennessey, C.J., dissenting in part). Another justice wrote that he felt the ruling to be required under Miranda, but added that it was "unjust":

Thus to curtail the evidence to be heard by the jury is not to improve the reliability of the jury's verdict. The justification for the exclusion of reliable evidence is said to be the deterrence of improper police conduct. But here the officers acted in good faith, attempting to observe proper legal standards. Their violation of those standards was not gross or wilful, was not of a kind likely to mislead the defendant, and did not create a significant risk that his statement that he left home at 6:30 A.M. may have been untrue. See Model Code of Pre-Arraignment Procedure $\S 150.3$ (1975).

369 N.E.2d at 705 (Braucher, J., concurring).

106. 369 N.E.2d at 698 (quoting Miranda, 384 U.S. at 450) (citations omitted).

107. 369 N.E.2d at 699 . 
time prior to his formal arrest. Yet Mathiason states plainly: "Miranda warnings are required only where there has been such a restriction on a person's freedom as to render him 'in custody." "108 In a footnote the Haas court distinguished Mathiason "by the fact that Mathiason came and left by his own choice. He arrived unaccompanied by anyone, and after the interrogation he was free to leave." 109

United States v. McCain ${ }^{110}$ involved a customs inspection at Miami International Airport. Customs agents suspected that the defendant might be smuggling narcotics into the country, ${ }^{111}$ and she was taken to a special room where two agents conducted a strip search. The search uncovered no incriminating evidence, but while the defendant's baggage was being checked a second time she was taken to another office and given a seven or eight minute warning about the dangers of carrying narcotics in body cavities. ${ }^{112}$ At that point the defendant confessed she was carrying narcotics in that manner. The court noted that it would "utterly distort" Miranda to hold that routine customs inspections, which necessarily involve an element of detention, render a person in custody. ${ }^{113}$ But the court went on to find that defendant had

108. 429 U.S. at 495 .

109. 369 N.E.2d at 699 n.7. With respect to the fact that officers accompanied Haas to the station, see note 98 supra and accompanying text.

In People v. Liccione, 63 App. Div. 2d 305, 407 N.Y.S.2d 753 (1978), the court found no custodial interrogation in a case factually similar to Haas. A woman who was fatally wounded by an intruder accused her husband of having hired the assailant. When the husband arrived home from work police detectives met him in the driveway and questioned him about several items of evidence they had discovered. Several of the detectives knew of the woman's accusation but did not inform the husband of it.

After about an hour, defendant was asked to go to the Public Safety Building for questioning and agreed to do so. The police officers testified that defendant was free to leave at any time and that they did not seriously suspect him until [later] . . . . Defendant testified that he believed he was in custody from the time he arrived [home] and that he thought he had no choice but to go to the Public Safety Building when requested to do so because he was under arrest.

Id. at 314, 407 N.Y.S.2d at 757. Applying the "reasonable innocent man" test, see text accompanying note 24 supra, and citing Mathiason, the New York Supreme Court, Appellate Division held that the interrogation at defendant's home was not custodial. 63 App. Div. 2d at 315, 407 N.Y.S.2d at 758.

110. 556 F.2d 253 (5th Cir. 1977).

111. A customs inspector had noticed that the defendant appeared nervous, her voice cracked and her clothing revealed a bulge in the abdominal area. Further, she was travelling alone, and her trip to Colombia had been short in duration. Id. at 254.

112. [T]he inspector talked to the defendant as "a father might talk to a daughter, and he told her that these were very serious matters, that she could harm herself seriously, perhaps even cause her death, if she was in fact carrying contraband in her body and if any of these containers ruptured and this narcotic substance was in immediate contact with her body or her internal organs."

Id. (quoting the transcript of the trial in the district court). The defendant had previously been shown a booklet of newspaper clippings about tragedies that had resulted under such circumstances. $I d$.

113. Id. at 255. See note 77 supra. 
been subjected to more than a routine customs detention and was in custody for Miranda purposes. ${ }^{114}$ One circuit judge dissented, expressing doubt that the defendant had been interrogated ${ }^{115}$ or that she had been any more in custody than had Carl Mathiason. ${ }^{116}$

In DiGiacomo, Brown, Haas and McCain, courts sensitive to the coercive potential of police interrogation all found a custodial interrogation requiring Miranda warnings, even though in each case the rationale of Mathiason might well have been taken to dictate the opposite conclusion. There are also other indications that the concerns that motivated Justice Marshall's dissent in Mathiason ${ }^{117}$ still occupy the courts. For example, in one post-Mathiason decision ${ }^{118}$ a state court indicated that questioning of a juvenile may be found to constitute custodial interrogation where there would be none were an adult involved:

Adolescents are more likely to succumb to the inherently coercive nature of police interrogation and the police should apply extra caution in dealing with juveniles .... A thirteen year old boy, with no previous experience with the police, taken to a police station without the benefit of parental guidance and subject to the pressures of an authoritarian atmosphere is more likely to reasonably believe that he

114. 556 F.2d at 255 (citing United States v. Garcia, 496 F.2d 670 (5th Cir. 1974), cert. denied, 420 U.S. 960 (1975); United States v. Salinas, 439 F.2d 376 (5th Cir. 1971)).

115. "She was rather warned-granted in a manner most frightening-of the risk she was running by carrying drugs internally. But the warning called for no response, and she knew when she received it that she had nothing more to fear from a strip search: she had already passed one." 556 F.2d at 256 (Gee, J., dissenting).

116. I also doubt McCain was in custody. Certainly the search of her person has [sic] been completed and she was not under formal arrest. She was merely waiting while her luggage was re-checked. Persons in such circumstances-waiting while their luggage is checked at the border-are not "in custody . ..." It is true she was in a private room, talking to the inspector. But so was Carl Mathiason . . . and so was Bertha Barfield . . . and neither was held to have been in custody.

Id. at 256-57 (Gee, J., dissenting). (The facts and holding in Barfield v. Alabama, 552 F.2d 1114 (5th Cir. 1977), are discussed at note 87 supra.)

With respect to their finding of custody, the majority in McCain wrote:

The government offered no testimony to the effect that Ms. McCain was free to leave after the initial strip search. In fact, all the evidence is to the contrary. However, if we were to assume Ms. McCain was not being physically restrained from leaving after the strip search, she was obviously able to leave only if she was willing to abandon her luggage, and this itself is a sufficient restriction on one's freedom of action so as to trigger the giving of Miranda warnings before proceeding with any interrogation.

$556 \mathrm{~F} .2 \mathrm{~d}$ at 255 .

117. See text accompanying notes 60-64 supra.

118. In re Hector G., 89 Misc. $2 d 1081,393$ N.Y.S.2d 519 (Fam. Ct. 1977). In that case, a 13year-old was asked by the police to accompany them to the precinct for further questioning. He was first allowed to go to his apartment, unescorted, to change his clothing. At the station the youth denied involvement in the crime. He was then told that if he told the "truth" he would be out in a "jiffy"; some time later he made an incriminating statement. The youth was questioned in a private room and was not give his Miranda warnings until after he made the incriminating statement. Id. at 1082, 393 N.Y.S.2d at 520 . The court concluded that the statement was the product of a custodial interrogation. Id. at 1084, 393 N.Y.S.2d at 521. 
is deprived of his freedom of movement. ${ }^{119}$

Courts generally have not interpreted Mathiason as a signal for substantial curtailment of the scope of Miranda protections, and the fears of some that Mathiason would largely negate Miranda ${ }^{120}$ seem to have been premature. Mathiason, after all, was a brief per curiam opinion decided upon a very skimpy record, ${ }^{121}$ and it did not deal with many of the policy considerations discussed so exhaustively in Miranda. Courts should hesitate to apply Mathiason beyond its own factual situation without a clearer directive from the Supreme Court that Miranda is indeed to be sharply restricted in its application. ${ }^{122}$

Another indication of continuing concern with the possibilities of coercion in police interrogations that are not "custodial" under the Mathiason rationale is the search for independent state constitutional requirements of Miranda-type warnings in such situations. Justice Marshall in his Mathiason dissent wrote: "It is . . . important to note that the state courts remain free, in interpretating [sic] state constitutions, to guard against the evil clearly identified in this case." 123 Vari-

119. Id. at 1084,393 N.Y.S.2d at 521 . In support of this conclusion the court quoted Haley v. Ohio, 332 U.S. 596 (1948), a pre-Miranda case in which a 15-year-old boy's confession was held involuntary: "[a juvenile] cannot be judged by the more exacting standards of maturity. That which would leave a man cold and unimpressed can overcome and overwhelm a lad in his early teens." Id. at 599 (opinion of Douglas, J., with three Justices concurring and one Justice concurring in result).

120. See note 67 supra.

121. See note 57 supra and text accompanying notes 57-58 supra.

122. One possible indication that the Court does not intend any sharp cut-back on Miranda rights came in Brewer v. Williams, 430 U.S. 387 (1977). The respondent in that case had been arraigned and jailed in Davenport, Iowa for abducting a 10-year-old girl in Des Moines. He was read his Miranda rights at that time. Attorneys advised him not to make any statement until he had consulted his lawyer in Des Moines, and the policemen who were to drive him to Des Moines agreed not to question him during the trip. However, one of the police officers knew that Williams was a former mental patient and was deeply religious. During the drive that officer told Williams that he thought they should stop and locate the girl's body so that she could be given a Christian burial. During the trip Williams made several incriminating statements, finally directing police to the body. Evidence relating to or resulting from Williams' statements was admitted at trial, and he was convicted. In subsequent habeus corpus proceedings one of the bases for the district court's conclusion that the evidence was wrongly admitted was that Williams had been denied the protections defined by Miranda. Williams v. Brewer, 375 F. Supp. 170, 180 (S.D. Iowa), affd 509 F.2d 227 (8th Cir. 1974), affd 430 U.S. 387 (1977). On certiorari the State of Iowa urged strenuously that Miranda be overruled and that "[t]he sole constitutional requirement for admissibility of an incriminating statement should be whether it is given voluntarily." Brief for Petitioner at 13, Brewer v. Williams, 430 U.S. 387 (1977). An amicus brief filed by, inter alia, the National District Attorneys Association and the Attorney Generals of twenty-one states also urged that Miranda be "abandoned." Brief for Amici Curiae at 3. The Court, however, refrained from doing so, deciding the case on the alternative grounds that Williams' sixth amendment right to counsel had been infringed. "[T]here is no need to review in this case the doctrine of Miranda $v$. Arizona . . . " 430 U.S. at 397 . Had substantial restrictions on Miranda been contemplated by the Court, Brewer might have been a good case in which to make them.

123. 429 U.S. at 499 (Marshall, J., dissenting). 
ous courts and commentators have picked up on this general theme in recent years, ${ }^{124}$ and several state courts have had occasion to consider it in the context of Mathiason.

In State v. Patterson, ${ }^{125}$ a suspect had been questioned at the scene of a crime and temporarily detained. While the Supreme Court of Hawaii held that Miranda warnings were not required in the situation before it, it noted by way of dictum that as a matter of state constitutional law it might not have reached the same result as the United States Supreme Court did on the facts presented in Mathiason, ${ }^{126}$ adding: "The protections to which an individual is entitled under Miranda also stem from an independent source in the Hawaii Constitution's privilege against self-incrimination." ${ }^{27}$

The Pennsylvania Supreme Court has also touched on the issue, noting in Commonwealth v. McLaughlin ${ }^{128}$ that

[i]n Pennsylvania "custodial interrogation" has been interpreted to mean either questioning. . . 'while in custody or while the object of an investigation of which he is the focus. . . .'

[B]y our placing of "object of an investigation" in the disjunctive with the custodial requirement, it might appear as though the Pennsylvania interpretation of when Miranda warnings are required was broader than the United States Supreme Court's interpretation. ...129

The court observed that the state had "the power to embellish the mini-

124. Among the examples cited by Justice Marshall in his dissent, $i d$, are: South Dakota v. Opperman, 428 U.S. 364, 384 (1976) (Marshall, J., dissenting); Baxter v. Palmigiano, 425 U.S. 308, 324, 338-39 (1976) (Brennan, J., dissenting); Michigan v. Mosley, 423 U.S. 96, 120-21 (1975) (Brennan, J., dissenting); Wilkes, More on the New Federalism in Criminal Procedure, $63 \mathrm{KY}$. L.J. 873 (1975); Wilkes, The New Federalism in Criminal Procedure: State Court Evasion of the Burger Court, 62 KY. L.J. 421 (1974).

Justice Brennan's dissent in Mosley observed that "[u]nderstandably, state courts and legislatures are, as matters of state law, increasingly according protections once provided as federal rights but now increasingly depreciated by decisions of this Court." 423 U.S. at 121 (Brennan, J., dissenting) (citing several specific examples). Justice Brennan has expanded on this same theme in a recent law review article. Brennan, State Constitutions and the Protection of Individual Rights, 90 HARv. L. Rev. 489 (1977).

In Opperman the Supreme Court reversed a South Dakota decision that routine inventory searches of impounded automobiles, made without probable cause or consent, violated the fourth amendment. The case was remanded for further proceedings not inconsistent with the opinion. 428 U.S. at 376 . On remand, the South Dakota Supreme Court found that such searches violated a nearly identical provision in the state constitution and upheld the suppression on that ground. State v. Opperman, _ S.D. _, 247 N.W.2d 673 (1976).

125. - Hawaii $\rightarrow, 581$ P.2d 752 (1978).

126. 581 P.2d at 754 .

127. Id. at 754 n.2 (citing State v. Santiago, 53 Hawaii 254, 492 P.2d 657 (1971)); see HawAll CONST. art. I, $\$ 8$.

128. 475 Pa. 97, 379 A.2d 1056 (1977).

129. Id. at 101, 379 A.2d at 1057-58 (quoting Commonwealth v. D'Nicuola, $448 \mathrm{~Pa} .54,57,292$ A.2d 333, 335 (1972)) (emphasis added by McLaughlin court). 
mum rights guaranteed in the United States Constitution based on our Pennsylvania Constitution." 130 However, it went on to say that in each of its prior cases "recognizing the defendant as the focus of an investigation, there was also present a degree of 'deprivation of liberty." "131 Noting that under neither test would the defendant have been entitled to Miranda warnings, ${ }^{132}$ the court did not decide whether the Pennsylvania Constitution ${ }^{133}$ in fact provided a broader guarantee than that recognized by the United States Supreme Court. ${ }^{134}$

The state constitutional provisions relied upon in Patterson ${ }^{135}$ and McLaughlin ${ }^{136}$ are substantially similar to the self-incrimination clause of the fifth amendment. This is also true in Alaska, ${ }^{137}$ where the question of an independant state constitutional guarantee was raised but not settled in a 1977 case, ${ }^{138}$ and in Michigan, ${ }^{139}$ where an appellate court rejected a similar claim. ${ }^{140}$

130. McLaughlin, $475 \mathrm{~Pa}$. at $103 \mathrm{n} .4,379$ A.2d at 1058 n.4; see PA. ConsT. art. $1, \S 9$.

131. $475 \mathrm{~Pa}$. at $102,379 \mathrm{~A} .2 \mathrm{~d}$ at 1058 .

132. Id. McLaughlin, a Philadelphia city employee, had submitted to an interview with the city controller in response to an administrative subpoena. The court relied primarily upon Beckwith v. United States, 425 U.S. 341 (1976); Mathiason was cited, but not discussed.

133. PA. Const. art. $1, \S 9$.

134. See McLaughlin, 475 Pa. at 102-03, 379 A.2d at 1058; Commonwealth v. Anderson, Pa. Super. _, 385 A.2d 365, $372-73$ n.13 (1978). The Anderson court wrote: "In McLaughlin, our Supreme Court intimated that [Article 1, Section 9 of the Pennsylvania Constitution] may encompass a higher standard of protection than the minimum standards of the federal constitution delineated in [Beckwith] and [Mathiason]." Id.

135. HaWAII Const. art. I, $\S 8$.

136. PA. Const. art. $1, \S 9$.

137. Alaska Const. art. I, $\S 9$.

138. Peterson v. State, 562 P.2d 1350 (Alaska 1977). In Peterson the Alaska Supreme Court was urged to extend "the principle of Miranda . . . to cover interrogation in non-custodial circumstances after a police investigation has focused on the [person being interrogated]." Id. at 1362. But the court found that there was no need to decide "whether [the Alaska] constitution extends to the accused any greater right to Miranda warnings than does the federal constitution," $i d$, since the defendant in that case in fact received warnings at the time the investigation focused on him.

139. Мich. Const. art. $1, \S 17$.

140. People v. Martin, 78 Mich. App. 518, 260 N.W.2d 869 (1977). Prior to Beckwith and Mathiason Michigan had employed the "focus" test in determining where Miranda warnings were required. See note 17 supra. The Martin case presented a situation in which suspicion had "focused" on the defendant, but he had not been deprived of his freedom of movement within the meaning of Mathiason. Police had entered a bar and asked to speak with Martin. He voluntarily accompanied the officers outside, telling them "you have to advise me of my rights." Before they did so they asked him if he owned a certain car (which they knew in fact to be stolen), and Martin answered that he did. 78 Mich. App. at 520, 260 N.W.2d at 870.

Under such previous Michigan cases as People v. Ridley, 396 Mich. 603, 242 N.W.2d 402 (1976), and People v. Reed, 393 Mich. 342, 224 N.W.2d 867 (1975), Miranda warnings should have been given. Those cases, however, had purported to rely upon federal constitutional standards which under Beckwith and Mathiason were clearly erroneous. The Michigan Court of Appeals considered the possibility of an independent state constitutional basis for the broader 
In Louisiana, however, the right to Miranda-type warnings "[w]hen any person has been arrested or detained in connection with the investigation or commission of any offense" is specifically provided by the state constitution. ${ }^{141}$ In State $v$. Segers, ${ }^{142}$ the defendant had voluntarily met the sheriff and answered questions before being advised of his rights. ${ }^{143} \mathrm{He}$ argued that even if Miranda were not applicable ${ }^{144}$ his rights under the Louisiana constitution had been violated. ${ }^{145}$ The court noted that "[d]efendant is correct when he argues that the term 'detained' might not mean the same as 'custody' under the Miranda cases." 146 But it went on to state that

[i]n interpreting the meaning of 'detained' it is essential to keep in mind the reasons for the requirement that police inform citizens of their constitutional rights prior to interrogation. Central to the purpose of this requirement is the protection of the individual's rights against self-incrimination from the coercive potential of police interrogation. ${ }^{147}$

Finding none of the "earmarks of coercion," the court concluded that there had been no "detention" within the meaning of the Louisiana constitution. ${ }^{148}$

"focus" test. The court noted that the fifth amendment and the state constitutional provisions on self-incrimination, Mich. CoNST. art. 1, $\$ 17$, were in fact identical. "Thus, the question arises as to whether any significant purpose is to be achieved by adopting a policy that places greater constraints upon police investigative activity. If so, then a rule more stringent than the United States Supreme Court's 'custody' standard is possible." 78 Mich. App. at 525, 260 N.W.2d at 872 . Finding no such purpose, the court determined that an incriminating statement the defendant made before receiving Miranda warnings was accordingly admissible:

A more stringent focus standard would lead to the anomalous result that in garnering sufficient evidence through the investigative process to establish probable cause for an arrest, that evidence may be subsequently excluded merely because a person questioned was a suspect and, at that time, the primary subject of an investigation. Such a standard disregards the circumstances under which the evidence was obtained and constrains legitimate, good faith investigative efforts, as well as misconduct by law enforcement officers.

Id. at $526-27,260$ N.W.2d at 873 .

141. LA. CoNST. art. $1, \S 13$. That section provides in pertinent part:

When any person has been arrested or detained in connection with the investigation or commission of any offense, he shall be advised fully of the reason for his arrest or detention, his right to remain silent, his right against self incrimination, his right to the assistance of counsel and, if indigent, his right to court appointed counsel.

142. 355 So.2d 238 (La. 1978), remanded for resentencing, 357 So.2d 1 (La. 1978).

143. 355 So.2d at 242 . The defendant had heard on the radio that an airplane in which he had an interest had been searched, $i d$, and over 3000 pounds of marijuana seized. $I d$. at 240.

144. The court, after comparing the facts with those in Mathiason, concluded it was not. Id. at 243-44.

145. Id. at 244. While the interview was cordial, the sheriff testified that he would not have permitted the defendant to leave after admitting an ownership interest in the plane. Later he testified that he did not know whether he would have allowed Segers to leave. Id. at 242.

146. Id. at 244.

147. Id.

148. Id 
While no state supreme court has yet interpreted a state constitution so as definitely to require Miranda-type warnings in situations that would not constitute custodial interrogation under the Mathiason Court's explanation of Miranda, there are indications that several courts at least are conscious of policy reasons supporting such an interpretation and may be willing to adopt it when an appropriate case arises.

\section{CONCLUSION}

The Supreme Court in Miranda held that "when an individual is taken into custody or otherwise deprived of his freedom by the authorities in any significant way . . . the privilege against self incrimination is jeopardized"149 and that in such circumstances procedural safeguards "must be employed to protect the privilege ...."150 The Miranda Court did not specifically deal with situations in which an individual not technically in custody or actually restricted in his freedom of movement is nonetheless subjected to the same sort of coercive pressures found to jeopardize the privilege against self-incrimination in Miranda-for example, the situation in which a person is "asked" to come "voluntarily" to the police station for questioning.

Some courts sought to effectuate what they saw as the underlying policy behind Miranda by including such situations in a broad interpretation of Miranda's definition of "custodial interogation"- "questioning initiated by law enforcement officers after a person has been taken into custody or otherwise deprived of his freedom of action in any significant way."151

Such a broad interpretation was decisively rejected by the Supreme Court in Oregon v. Mathiason, which took a much more restrictive view emphasizing technical custody or actual, physical deprivation of the individual's freedom to walk away from police questioning. Nonetheless, the decisions of state and federal courts since Mathiason indicate that those who saw that case as a sharp setback for fifth amendment rights may have been too pessimistic. The courts have shown little tendency to rely upon Mathiason to hold interrogations to be noncustodial in situations not closely analogous to that in Mathiason itself. Indeed, some courts have continued to find custodial interrogations in situations in which Mathiason would seem to dictate an opposite result. Moreover, at least a few state courts have

149. 384 U.S. at 478.

150. Id. at $478-79$.

151. Id. at 444. 
indicated a possible willingness to find, under state constitutional provisions, a broader area in which Miranda-type warnings are required than that suggested by Mathiason. Thus, Mathiason may prove only a temporary check in the progress towards general acceptance of the value of Miranda warnings in situations where a person not in custody or actually restricted in his movement is nonetheless subjected to coercive pressures in police questioning.

W. Steven Woodward 